Т. В. Маменко, аспірант Інституту філософії імені Г. С. Сковороди НАН України e-mail: zlokara@i.ua ORCID: https://orcid.org/0000-0003-1189-5711

\title{
ПОРІВНЯЛЬНИЙ АНАЛІЗ КОНЦЕПЦІЙ ЗНАКУ У ДЖ. БЕРКЛІ ТА ДЖ. ЛОКА
}

У статті розглядаються семіотичні погляди Дж. Берклі як алтернативні відносно парадигмальних для епохи поглядів Дж. Лока. Відкидаючи матеріалістичну онтологію, Берклі переосмислює значення мовного знаку. Оскільки ідеї перестають відсилати до речей, а речі є комбінацією простих ідей, своє значення мовні знаки (слова) отримують завдяки зв'язку між ідеями. Це дає niдставу говорити про функиіональне значення знаку на відміну від субстанційного, де за словом має стояти конкретна матеріальна річ, чи чітка ідея. Показано розширення Берклі функиіонування мови, мова потрібна не лише для передавання інформації, вона може виражати емоції, волю, переконання тощуо.

Ключові слова: Дж. Берклі, Дж. Лок, знак, мова, слово, ідея, річ, відчуття, семіотика.

Сформульована в семіотиці Лока концепція знаку була домінантною та навіть парадигматичною в модерній філософії мови. Мова, за Локом, є вторинною щодо репрезентованої розумом реальності. Вона є, насамперед, засобом повідомлення ідей, зовнішньою маніфестацією внутрішнього стану людини. Мова може виконувати свою репрезентативну функцію тому, що слово є знаком певної ідеї, а ідея, своєю чергою, є знаком речі. Словесний знак, як і мова загалом, є інструментом фіксації та пере-

(C) Маменко Т. В., 2019 
давання знання. I хоча найсильнішого удару цій концепції було завдано «мовним поворотом» у ХХ ст., проте вже сучасники Лока та його найближчі наступники почали розхитувати підвалини його семіотики, критикуючи спрощення емпіристської теорії ідей та i бажання обмежитися винятково «механікою ментального». Серед них варто згадати Г. Ляйбніца, Е. Кондільяка i, звичайно, Дж. Берклі, який, пориваючи з матеріальною субстанцією, відкидаючи абстрактні поняття та вказуючи шлях до дійсності через природні та умовні знаки, заклав основу, на якій згодом виникне нова семіотична традиція. Мета нашої розвідки розкрити основні семіотичні ідеї Дж. Берклі як альтернативу семіотиці Лока в модерній філософії, яка не була гомогенною (зокрема в мовно-семіотичній проблематиці), та показати нові обрії розуміння знаку, які відкриває критичний аналіз Берклі.

\section{I}

Для початку стисло охарактеризуємо основні ідеї знакової концепції Дж. Лока, який у цілому мислив свій проект філософії як семіотичний ${ }^{1}$. В останній главі свого головного твору «Нарис про людське розуміння» Дж. Лок поділяє всі науки за предметом, чи тим, що потрапляє в поле зору нашого розуму, на три види [Essay, IV, 21:1]. По-перше, фізика, яка вивчає речі як вони $\epsilon$ самі по собі. Щоправда, в іншому місці Лок сумнівається в можливостях подібної науки, адже ми ніколи, на його думку, не прийдемо до достовірності в пізнанні субстанцій, через дослідження і опис ми не можемо проникати у внутрішню будову $\mathrm{i}$ реальну сутність тіл [Essay, IV, 12:10]. По-друге, практичні науки і головним чином етика, що шукає щастя і шляхи до нього. У

${ }^{1}$ Варто лише подивитися на розділи Локового «Нарису про людське розуміння». Перші два розділи присвячені ідеям як знакам, третій - словесним знакам, а четвертий - істині, яка у Лока теж визначається семіотично: «Істина є об'єднання чи розділення знаків відповідно до того, узгоджуються чи не узгоджуються речі, що ними позначаються» [Essay, IV, 5:2]. 
цій науці Лок не сумнівається і сподівається, що вона може стати достовірною. І третя наука, Лок називає іiі грецькою мовою

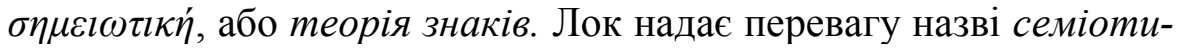
$\kappa a$, а не логіка, оскільки ця наука має займатися дослідженням знаків. Під знаками Лок розуміє не лише слова, а й iдеї. Традиційна логіка займалася словами, але таким чином, що вела до пустих схоластичних суперечок. Семіотика ж має зрушити з місця філософію і дати їй можливість по-новому вирішити іiі традиційні проблеми. Відповідальне ставлення до знаків дасть змогу уникнути помилок у мисленні і дасть розвиток наукам, загнаним схоластикою у суперечності і безпліддя. Завдання такої науки - розглянути природу знаків, якими розум користується для осягнення речей і для передавання свого знання іншим.

Наука, за Локом, має справу не із самими речами, а з їхні-

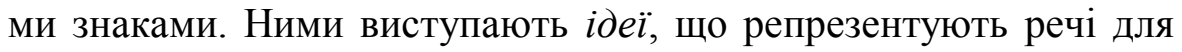
нас, та слова, що репрезентують наші ідеї для інших. Лок наполягав, що можна звільнитися від помилок, яким ми схильні піддаватися, сприймаючи слова за речі, тим самим виступив проти своїх земляків францисканців Р. Бекона та Д. Скота на користь Т. Аквінського ${ }^{2}$. Як і Тома, він атакує вродженні ідеї і стверджує, що пізнання починається з відчуттів і лише потім переходить до понять. Лок виокремлює також реалістичну й емпіричну позицію останнього ${ }^{3}$. Звісно, емпіризм Лока виростає на зовсім нових засадах.

У розділі «Нарису», спеціально присвяченому мові, Лок стверджує, що кожна людина має різноманітні ідеї, які замкнені в iї індивідуальному розумі, вони є невидимими та прихованими

${ }^{2}$ Середньовічні автори по різному розв'язували питання, що саме позначає слово - поняття (С. Боецій, Т. Аквінський), чи саму річ (Р. Бекон, Д. Скот), чи те й інше, але в різний спосіб (Коїмбрські коментарі кінця XVI ст. на твори Аристотеля).

3 Про емпіризм Томи див.: С. Свежавский. Св. Фома, прочитанный заново. Символ, № 33, 1995. 
від інших. Із метою комунікації з іншими ми вигадуємо чуттєві знаки, за допомогою яких наші думки можуть бути виражені для інших. Найбільше для виконання цієї ролі підходять артикульовані звуки, якими люди природно можуть легко оперувати та довільно вибирати. Оскільки зв'язки між артикульованими звуками та певними ідеями є довільними, існують різні мови. Призначення слів - бути чуттєвими знаками ідей.

У сучасній філософії, хоч про що ми говоримо, ми говоримо першою чергою про слова. Вирватися за межі слів так само важко, як модерній людині вирватися за межі ідей. Для емпіризму Нового Часу мова $є$ вторинною, ідеї є первинними. Але що таке ідеї, незалежно від мови? На це питання модерн не дає задовільної відповіді.

Для Лока ідеї стоять ближче за все до речей. Хоча він і застерігає, наскільки іноді важко відокремити мислення ідеями від словесного. Слова ніби обслуговують ідеї; якщо за словом не стоїть ідея, то воно не має сенсу. Під ідеями Лок розуміє все, що є об'єктом мислення. Об'єктом мислення щось може стати через відчуття (кольори, запахи, звуки тощо) або через рефлексію (поняття, вид тощо) [Essay, I, 1:8]. Лок переконаний, що можна мислити прості чисті ідеї без слів (як приклад, він наводить ідеї: «біле», «гірке», «трикутник» [Essay, IV, 5:4]). Для Лока не очевидно, що, наприклад, «біле» можливе лише там, де вже є впорядкована мовою система кольорів. Сучасна психолінгвістика досить переконливо засвідчує, що кольорові палітри в різних народів залежать від їхньої мови ${ }^{4}$.

Онтологія Лока передбачає існування тілесних субстанцій, які стоять за ідеями та існують самі по собі, хоча ми і не можемо пізнати їхню сутність. Відповідно прості Локові ідеї є знаками реальних тіл з їхніми первинними та вторинними якостями. I хо-

\footnotetext{
${ }^{4}$ Див. грунтовну працю лінгвіста Г. Дойчера «Сквозь зеркало языка: почему на других языках мир выглядит иначе», АСТ, 2018
} 
ча вторинні якості - так, як вони нами сприймаються, не існують у тілах (самі тіла не сині, не теплі і не солодкі), там є об'єм, форма і рух непомітних частинок, який ми сприймаємо як колір, запах тощо. А первинні якості цілком реальні та існують у самих речах, вони доступні нашому безпосередньому сприйняттю. Так, наші ідеї форми, числа, руху стосуються безпосередньо самих речей, вони схожі до них. Слова, за Локом, відсилають до ідей, а ті, своєю чергою, до речей. Прості ідеї є знаками, які Бог встановив для розрізнення речей і користування ними [Essay, II, 32:14]. Таким чином, між річчю в Лока і нашими ідеями існує постійний зв’язок. Річ своєю присутністю впливає на нас, своїми властивостями спричиняє формування наших простих ідей про неї. Вони здебільшого мають бути однаковими в людей. Якби, твердить Лок, прості ідеї не збігалися, люди взагалі не змогли б спілкуватися і розуміти одне одного [Essay, II, 13:28]. Нечутливість до мови і тут підводить Лока. Зв'язки слід шукати не між речами та ідеями (адже доступу до речей в безпосередній спосіб у нас немає), але в нашій мові. У дальтоніків, наприклад, речі червоного кольору не викликають ідеї червоного. Поняття значення з чуттєвого досвіду вивести не можливо.

Лок стверджує, що слова є знаками, які позначають ідеї, або мають їх позначати, щоб не бути беззмістовними. Оскільки люди не можуть безпосередньо обмінюватися думками, вони змушенні вживати чуттєвих знаків, призначення яких викликати в розумі іншого ту саму ідею, що і в мовця [Essay, III, 1:2]. Тут відразу постає проблема приватної мови, проти якої виступав Л. Віттгенштайн. Оскільки наші ідеї є приватними, ми не можемо бути певними чи ідеї іншого, які є його власними ідеями, отриманими в його власному досвіді $є$ тими самими. Усі ідеї $є$ внутрішніми, зачиненими в розумі індивіда. А слова лише позначають ці, можливо, більш-менш схожі ідеї. Для Лока проблеми тут немає, адже на його переконання прості ідеї дані нам у відчуттях. Проте, як зауважили б раціоналісти, щоб мислити (ві- 
дчувати) червоний колір, необхідно, щоб у свідомості вже було поняття кольору. Фактично загальне поняття має передувати конкретному. Далі, продовжує Лок, мислення передається реченнями, які мають викликати в розумі того, хто слухає, послідовність ідей, якщо ідеї не виникають, то мова не має сенсу. Часто люди зловживають словами, не маючи за ними жодних ідей, або чітких ідей. Лок навіть плекає надію, що якби люди у своїх судженнях визначали б терміни, а їхнє значення зводили б до сукупності простих ідей, то суперечки зникли б з лиця Землі [Essay, III, 11:7].

Як відзначає Лок, слова позначають переважно не конкретні речі, що було б неможливо через їхню велику кількість, а загальні ідеї (людина, кінь). Слова мають загальний характер через те, що їх роблять знаками загальних ідей, а ідеї своєю чергою стають загальними через процедуру абстрагування, тобто відділення від обставин місця, часу, а також всього індивідуального [Essay, III, 3:6]. Завдяки абстрагуванню, вважав Лок, і з'явилася мова. Слова можуть бути загальними в тому сенсі, що не мають точного значення, яке полягає в абстрактних загальних ідеях; вони позначають велику кількість конкретних ідей.

\section{II}

Як зазначає В. Декомб в «Інституціях сенсу», новий час не мав філософії мови в тому сенсі, як ми їі маємо зараз: «Починаючи від Декарта, Гобса чи Лока і аж до Гегеля та Ніцше відправним пунктом роздумів про мову є не концепт знака, який покликаний щось сказати, а той, який покликаний щось фігуративно представити» [7, с. 109-110]. Репрезентативні ідеї не можуть бути знаками речей, знак завжди відсилає до свого значення, а репрезентативна ідея ні до чого конкретно не відсилає, вона не забезпечує нам доступу до речей. Проте, вже в Берклі з новою онтологією намічається поворот до не репрезентативного розуміння знаку.

Institute of Philosophy of H. S. Skovoroda of NAS of Ukraine 
Дж. Берклі переймає Локівську термінологію і в цілому продовжує його проект, для нього знаки також $є$ важливим предметом дослідження, хоча він і протистоїть Локу в їхній інтерпретації. «Я схильний вважати, - пише Берклі, - вчення про знаки предметом надзвичайно важливим, яке, якщо досліджувати його належним чином, проллє чимало світла на природу речей і допоможе слушно та істинно вирішити багато труднощів» [Alciphron, VII, 13].

Берклі також переконаний у тому, що він може уникнути помилок, звільнивши своє мислення від слів і залишивши там самі ідеї [Treatise, Int, 22]. Мислення має справу з ідеями, а слова потрібні для комунікації, відповідно головна увага приділялася саме ідеям.

Берклі приймає поділ Локом знаків на ідеї та слова, проте кардинально переосмислює їхнє значення. Зовнішні ідеї в Берклі стають природними знаками. Відкидаючи існування тілесних субстанцій, він змушений повністю переосмислити референцію ідей як знаків. Якщо ідеї не відсилають до матеріальних речей, то в чому полягає їх значення? Для розв'язання цього питання Берклі пропонує свою теорію Зору або «мови зору» (в подальшому розкритті цієї теорії спиратимемось головним чином на четвертий діалог «Алсіфрону». - T.M.). Бог говорить очам так, запевняє Берклі, як інша людина говорить вухам [Alciphron, IV, 12]. Наш зір є мовою Творця природи, стверджує Берклі, людина отримує від Бога через органи чуттів різні знаки (ідеї), які вона вчиться розуміти і впорядковувати, використовувати для власної користі. Знаки системно організовані в певний порядок і $є$ мовою Бога, спрямованою до нас. Світло і кольори утворюють цю мову своїми різноманітними поєднаннями, вона пристосована до того, щоб навіювати (suggest) нам відстань, положення, фігури, розміри та інші властивості речей, які ми можемо сприймати через дотик, не через подібність, не через логічний висновок, а завдяки довільному рішенню Провидіння, так 
само, як слова викликають у нашій уяві речі. Завдання філософа - розшифрувати ці символи (знаки), які не є виключно математичними, як думав Галілей. Необхідно відкрити правила граматики, щоб розшифрувати мову, якою написана книга природи, $\mathrm{i}$ на їі основі робити вірні прогнози. Берклі хоче обмежитися ідеями і постулювати їх достатність для референції. Як відомо, слово не потребує внутрішньої схожості 3 предметом, щоб мати значення, так само, каже Берклі, і слова природи: поєднання ідей світла, кольорів, запахів - не потребують предметів, а лише досвіду і звички.

Ця мова схожа на людську мову. Адже розмаїття кольорів у різних поєднаннях дає, як і розмаїття звуків, безмежну кількість знаків, які утворюють, відповідно, дві мови - Божественну і людську. Одна буде природною, інша - штучною. Як відомо, слова не мають необхідного зв'язку з ідеями, одну і ту саму ідею можна по різному називати. Схожим чином, стверджує Берклі, знаки чуттів між собою не пов'язані необхідно. Малий розмір речі, що спостерігається здалеку, не пов'язаний необхідно з відстанню. Лише досвід вчить нас, що річ при віддаленні зменшується в розмірі та чіткості. Сліпий, який прозрів, не матиме одразу ідеї, що предмети, які він бачить, знаходяться на відстані чи мають ту чи іншу форму. Як і Лок у «проблемі Моліне» про сліпого, який став зрячим і якому показували на відстанні куб і шар для їх розрізнення без дотику, - Берклі займає негативну позицію. Щоб навчитись розуміти мову зору йому потрібен досвід. ${ }^{5}$ «Немає, - твердить Берклі в іншому місці, - більшої необхідності виводити речі, що сприймаються через дотик, з модифікацій світла, ніж у мові робити висновки про сенс сказаного зі звуків, але так само, як існує зв'язок між різними тонами і артикуляціями голосу та їхніми різними значеннями, таким же чином існує зв'язок між різними видами світла та їхніми корелятами. Іншими

${ }^{5}$ Див. сучасні експерементальні підтвердження в книзі сучасного американського психолога Олівера Сакса «Антрополог на Марсі», гл. 4. 
словами, між ідеями зору та дотику» [The Theory of Vision, 40]. Схожим чином у Трактаті: «зв'язок ідей не передбачає причинно-наслідкового зв'язку, а лише відношення знаку до того, що ним позначається. Видимий мною вогонь не $є$ причиною болі, що я відчуваю, а лише знак, що мене застерігає (mark) [Treatise, 65].

На відміну від звичайної мови - мова зору засвоюється кожним 3 перших днів життя, вона єдина для всіх народів. Як і Лок, Берклі категорично не сприйняв би гіпотези лінгвістичної відносності Сепіра-Ворфа, для нього не мова має впливати на мислення та ідеї (подібне вело б до нескінечних суперечок і непорозумінь), а навпаки. Знаки, які ми сприймаємо, походять від Провидіння: кольори, звуки, форми тощо є однаковими.

Люди помилково схильні ототожнювати об'єкти зору з речами в той самий спосіб, як вони іноді плутають слова з речами. Наш розум не затримується довго на знаках, а переходить відразу до речей, що ними позначаються, таким само чином, як ми не зосереджуємося на буквах, читаючи книгу. На відмінну від умовності мови слів, зв'язок між відчуттями $є$ встановленим Богом, відповідно він одноманітно ідейно виражається. Фактично річ $€$ складною ідеєю у термінології Лока, або зібранням (collection) відчуттів. Між річчю і простими ідеями існує чітка кореляція, встановлена Провидінням.

Бог поєднує ідеї певним порядком і являє їх людям. Таким чином вони не $\epsilon$ хаотично розкиданими, а системно організованими. Розум з досвіду помічає, що певна кількість ідей існує постійно разом, для нас вони стають речами. Через ідеї за допомогою розуму ми відрізняємо речі за їх природою, місцем і часом існування. Це не Бог деїстів, він не просто Творець, який творить світ як годинник, заводить його і залишає, він Правитель, який створює вмить безкінечну кількість знаків, які поєднуються, змінюють місце і форму, знаків, пристосованих до безкінечної множини цілей і обставин. Через ці знаки Бог вчить нас і на- 
правляє. Подібна мова природи певніша за будь-які науки, вона діє постійно, незмінно і одноманітно. Вона несе людям радість від споглядання прекрасного, відповідає потребам людей, інформуючи про небезпеку від речей і їхню користь для нас.

В останній своїй праці Берклі дедалі більше тяжіє до раціоналізму. Яким чином свідомість організовує ідеї? У самих явищах природи існує певна аналогія, постійність, закономірність, або граматика природи, яку потрібно розкрити. Відчуття (sense) саме по собі нічого не знає. Сприймаючи звуки, ми їх ще не розуміємо, каже Берклі. «Тварина, схожа на людину, яка чує дивну мову, але нічого не розуміє» ${ }^{6}$. Лише розум здатний осягнути розумну мову творця природи і лише незначною мірою. Далі Берклі взагалі відмовляється від своєї формули esse est percipi, стверджуючи, що лише буденна свідомість ототожнює чуттєве 3 реальним, принципи науки не є об'єктами чуттів і тільки інтелект та розум єдині істинні провідники на шляху до істини ${ }^{7}$. Берклі повертається до платонового раціоналістичного розуміння ідеї. Якщо в своїх ранніх трактатах Берклі заперечував значення мови, то тепер можна спостерігати, як чуттєва основа світу підміняється суто символічною, світ постає як мова.

Можна тепер дати відповідь на питання про референцію у Берклі. Онтологія Берклі передбачає існування лише духовних субстанцій, відповідно, за нашими ідеями може стояти або Бог, i це будуть природні знаки, або кінечні духи - мовні знаки і знаки уявні [1]. Природні знаки у Лока і в цілому в середньовічній традиції схожі до самих речей, для Берклі вони вже не так репрезентують річ, як конституюють іï за певними правилами. Бог безпосередньо навіює нам через знаки природи ментальну ідейну реальність, в якій ми живемо. Знаки не існують ізольовано, вони перебувають у постійному зв’язку між собою, спостерігаючи за

\footnotetext{
${ }^{6}$ The Works of George Berkeley Bishop of Cloyne Edited by A. A. Luce uud T. E. Jessop v.5 p.121.

${ }^{7}$ Ibid... p. 124.

40
}

Institute of Philosophy of H. S. Skovoroda of NAS of Ukraine 
знаками, ми об'єднуємо їх у речі і формулюємо зв'язки між ними. Не існує ідеї, яка не відсилала б до іншої ідеї, пов’язаної 3 нею. У речах поєднані ідеї кольору, запаху, форми тощо. Корелятом знаку може бути схожий на нього образ, дія, причина (як ми собі їі уявляємо) чи просте співіснування, все це є підставою, щоб один знак відсилав до іншого, хоча такий зв'язок і є випадковим. Ідея отримує своє значення в своєму відношенні з іншими ідеями і в своєму практичному значенні для потреб людини. Ідея дається в чуттях, внаслідок впливу на наші чуття ми отримуємо певне уявлення (ідею) гарячого, яскравого, білого. Мова природи вчить нас краще за все, вона з легкістю засвоюється, ще 3 малечку вчить нас розрізняти предмети, дає неймовірну кількість інформації, один лише погляд дає, стверджує Берклі, більше корисних порад, чіткого розуміння речей, ніж багатогодинна лекція. Вона відповідає потребам людей, повідомляючи про небезпеку і корисність речей. Берклі пропонує уявити незрячий народ, до якого завітала єдина зряча людина і міру їх здивування, коли та відразу розказала їм про розташування предметів навколо них.

Тепер варто розглянути питання про інші знаки, якими послуговуються люди - слова. На абстрагування в концепції Лока Берклі нападає найбільше, адже, на його думку, воно призвело до великих труднощів у науці. Абстрактні загальні ідеї не можливі не лише в дійсності, з чим і Лок погоджується, будучи номіналістом, вони неможливі навіть в уяві. Абстрактного трикутника не можна уявити, наполягає Берклі. Він би мав бути усім $\mathrm{i}$ нічим одночасно, не великим і не малим, не гостро- і не тупокутним i, водночас, об'єднувати в собі всі ці протилежні якості. [Treatise, Int, 13]. Слово стає загальним, каже Берклі, коли воно є знаком не абстрактної загальної ідеї, а багатьох часткових, будьяку з яких воно без різниці викликає в нашому розумі. [Treatise, Int, 12]. Лінія на дошці в класі намальована крейдою, має конкретну довжину, колір і навіть ширину, проте це не заважає ій бу- 
ти знаком, що відноситься до будь-якої лінії. Абстрактні ідеї не потрібні для розширення нашого пізнання, на чому наполягав Лок. Хоча всяке пізнання здійснюється над загальними поняттями, але такі поняття утворюються не через абстрагування. Часткова за своєю природою річ стає загальною. Так, у геометрії за зразком часткового трикутника доводять теорему, яка стосується всіх трикутників [Treatise, Int, 15]. Загальне знання має справу зі знаками, які стають такими за своїм значенням, а не своєю природою.

На думку Берклі, саме абстрактні ідеї ведуть до матеріалізму. Вони постулюють існування неможливих, суперечливих реальностей. Так, уявлення в розумі абстрактної ідеї протяжності тягне за собою уявлення про іiі існування. Але помислити абстрактну ідею протяжності не можливо.

Щодо стосунку слів до ідей, Лок, як ми вже відзначали, вимагав, щоб за словами завжди виникали в розумі чіткі ідеї. Берклі і тут не погоджується. Просте спостереження за людською розмовою показує, що в тому немає необхідності, часто слова використовуються як алгебраїчні символи, що замінюють певне число. Непотрібно кожен раз, зустрічаючи подібний символ, уявляти ту конкретну кількість, що позначається числом [Treatise, Int, 19]. Деякі символи і уявити неможливо, проте вони корисні для науки. Крім того в Берклі слова, які стосуються активного начала або духа, не можуть відсилати до ідеї, адже вона пасивна. Берклі постулює можливість неідейного пізнання. Об'єм людського знання ширший за ідеї, ми не маємо ідей відносин, дій - це скоріше поняття. Говорячи про поняття (notion), Берклі протиставляє їх ідеям. Поняття отримує своє значення не від ідеї, але розум постулює його. Поняття має не скільки значення, скільки сенс, якщо скористатися термінологією Фреге. Так, нам відомі поняття: «Я», «Воля», «Пам'ять», «Любов», «Ненависть», хоча слова ці і не передбачають чітких ідей [Alciphron, VII, 8]. Почуття страху, любові, ненависті, захоплення, зневаги тощо виникають негайно після сприйняття певних слів, без посеред- 
ництва будь-яких ідей між ними [Treatise, Int, 20]. Слово може мати значення не тому, що воно позначає ідею, а тому, що воно $€$ складовою системи знаків, якими наш розум позначає зв'язок наших думок, дій, емоцій.

Лок вбачає головне призначення мови в повідомленні наших думок та ідей іншим [Essay, III, 11:23], що викликало справедливе заперечення з боку Берклі, адже мова може мати і інші цілі: формувати почуття, впливати на нашу поведінку тощо. Практичний вплив слів більш важливий за їхнє значення, людина говорить, щоб переконати чи наставити іншого, примусити співбесідника до певних дій, налякати чи підбадьорити. До простого повідомлення ідей люди прагнуть досить рідко.

Скажімо кілька слів про роль знаків у науці. За Локом, завдання філософії полягає в тому, щоб очистити мову від випадкового слововжитку, чітко визначати поняття, перелічуючи його основні складові, які можна звести до простих ідей. Усе це робиться в цілях пізнання. Берклі стверджує, що людська душа природнім шляхом отримує ідеї не для простого споглядання їх, а для дій над ними, тобто привносить у науку прагматичний елемент. Науки і мистецтво мають виробити необхідні загальні правила, щоб привести людину до щастя. Свої правила науки отримують за посередництва знаків чи символів, які завдяки своїй загальній природі стають знаряддями для них. Наш розум просувається вперед у пізнанні не за допомогою споглядання речей, чи абстрактних ідей, а завдяки вдалому вибору і вмілому використанню знаків чи символів. Знаки вказують на зв'язки між речами. Усі науки мають справи зі знаками, хоча ті і відносяться до речей. Знаками легше оперувати, ніж складними об'єктами, а ми схильні відоме робити сходинкою на шляху до невідомого. «Обираємо знаки чуттєві, головним чином зорові, оскільки зір найбільш ясне, чітке, приємне та всебічне відчуття. Людині цілком природньо допомагати інтелекту через уяву, уяві через відчуття, іншим відчуттям через зір першою чергою. Звід- 
си малюнки, метафори і символи (figures, metaphors, and types). Ми ілюструємо духовні речі тілесними, на місце думок ставимо звуки, на місце звуків - букви. Емблеми, символи та ієрогліфи ставимо на місце речей надто темних, щоб їх сприймати, чи розмаїтих та швидкоплинних, щоб їх утримати в пам'яті» [Alciphron, VII, 13]. Ми замінюємо наші розумові речі уявними, чуттєвими уявні, надто великі - меншими, надто маленькі - більшими. Звідси моделі та схеми. Ми говоримо образно про речі духовні, запозичуючи терміни зі сфери чуттєвого. Звідси метафори й алегорії у мові.

Система знаків, якою користується людство, є умовною, не варто приписувати певний універсальний і субстанційний сенс поняттям фізики, вони є одним із способів упорядкування фактів і мають значення лише в контексті нашого практичного відношення до природи. Берклі пропонує варіант побудови математичної символічної системи 3 «нуля» (Alciphron, 15). Так, називаючи імена в певному порядку, можна виразити нескінчену ступінь числа, винайденим, незмінним по природі і доступним зору знакам можна давати чітко підібрані імена. Подібні позначення полегшують відкриття і застосування загальних правил у мисленні й оперуванні числами. Розум матиме справу виключно зі знаками, без всякого при цьому уявлення про конкретні речі. Система запису чисел еволюціонувала від запису словами, через запис літерами, римськими цифрами i, нарешті, алгебраїчними символами. Останнім, завдяки своїй зручності та універсальності застосування, необхідно надати перевагу. Математика як наука багато чим зобов'язана вмілому вибору символічної системи. Тут Берклі додає, що своїм вжитком знаки вказують на зв'язки, $\mathrm{i}$ не мають нічого спільного з абстрактними ідеями.

Підводячи підсумки можемо відзначити, що Берклі, завдаючи удар традиційній модерній онтології, закладає фундамент несубстанційного підходу в розумінні знаку. У Лока, словесний знак отримує своє значення від ідеї, яка за ним стоїть і яка своєю чергою бере своє значення від речей. Берклі, аналізуючи Мову 44

Institute of Philosophy of H. S. Skovoroda of NAS of Ukraine 
зору, відзначає, що знак вказує на зв'язок між речами, що дає нам підстави говорити про функціональне значення знаку. Берклі розуміє, що знаки пов'язуються нами за певними правилами відповідно до різних критеріїв (час, місце, каузальність тощо) та практичних потреб. Слово для нього не втрачає сенсу, якщо воно не має чіткої ідеї, що за ним стоїть. Проект науки, який постулював Лок, де за кожним терміном стоятиме чітка ідея, у Берклі приречений на невдачу. Берклі переконливо критикує традиційні для фізики поняття сили, субстанції, простору, що дало підстави К. Попперу [8] стверджувати про «бритву Берклі», яка значно гостріша за Окамову, та засвідчує невдалість есенціалістських пояснень у науці.

Важливим є також розширення функціонування мови, яке ми спостерігаємо в Берклі. Лок розглядає мову лише як засіб комунікації, для Берклі комунікація є однією, до того ж не самою важливою, функцією мови. Хоча Берклі відчуває необхідність шукати загальні значення не в речах, а в стосунках між ідеями, проте не розуміє, що неможливо пояснити загальні ідеї лише механікою простих ідей, загальні значення набуваються завдяки мові. Мова не $є$ вторинною для набуття ідей, як вважали класичні емпіристи, вона необхідна для пізнання та мислення. Подальша критика емпіричного ідеалізму довела, що загальні ідеї передують сприйняттю конкретних речей, і ми засвоюємо ці ідеї завдяки мові, але не в теоретичний спосіб, а у практичний: дитина, яка засвоює слово «трикутник», наприклад, не просто дізнається, що існують трикутники, а здатна застосовувати це слово до речей світу, ідентифікуючи трикутники.

Критика Берклі матеріальної субстанції мала великий вплив на подальший розвиток філософії. Пірс не даремно стверджував, що він проповідує не формульований метод Берклі. Наша ідея якоїсь речі, за Пірсом, є ідеєю иї чуттєвих наслідків. Для Пірса, як і для Берклі, цього достатньо і не потрібне постулювання жодних речей самих по собі. Цими чуттєвими наслідками 
обмежується об'єкт, у ньому нічого більше немає. Пірс і сам не заперечував, що Берклі ввів прагматизм у філософію, а він лише його чітко сформулював. Пірсів принцип «бути, значить мати практичні наслідки», є перефразом «еsse est percipi» у Берклі, зауважує радянський дослідник філософії Пірса Ю. Мельвіль [7, с. 362].

\section{ЛІТЕРАТУРА}

1. Gowan W. Mc. Berkeley's Doctrine of Signs In Colin M. Turbayne (ed.), Berkeley : Critical and Interpretive Essays Manchester University Press, 1983. xii + 340 pp.

2. Locke John: An Essay concerning Human Understanding Ed. by Alexander C. Fraser in 2 Volumes. Clarendon Press, 1894.

3. The Works of George Berkeley. Ed. by Alexander C. Fraser. In 4 Volumes. Oxford : Clarendon Press, 1901.

4. The Works of George Berkeley Bishop of Cloyne Ed. by A. A. Luce and T. E. Jessop. Vol. 5 London : Thomas Nelson and sons ltd. 1953

5. Winkler $K$. Berkeley and the doctrine of signs in The Cambridge Companion to Berkeley Cambridge University Press. 2005. 406 p.

6. Декомб В. Інституції сенсу. Київ : Український центр духовної культури, 2008.

7. Melvil Yu. K. Charles Pierce and pragmatism. M., 1968. 500 pp.

8. Поппер $K$. Заметки о Беркли как предшественнике Маха и Эйнштейна // Вестник новгородского государственного университета. 2000. № 16.

\section{REFERENCES}

1. Gowan, W. (1983). Mc. Berkeley's Doctrine of Signs In Colin M. Turbayne (Ed.). Berkeley: Critical and Interpretive Essays. Manchester University Press.

2. Locke, John (1894). An Essay concerning Human Understanding. Clarendon Press.

3. The Works of George Berkeley. (1901). Oxford: Clarendon Press.

4. Luce, A. A. \& Jessop, T. E. (Eds.) The Works of George Berkeley Bishop of Cloyne. Vol. 5. London: Thomas Nelson and sons ltd. 
5. Winkler, K. (2005). Berkeley and the doctrine of signs. Cambridge: Cambridge University Press.

6. Decombe, B. (2008). Institutions of meaning. Kyiv: Ukrainian Center for Spiritual Culture. [In Ukrainian].

7. Melvil, Iý.K. (1968). Charlz Pırs ı pragmatızm. Moscow.

8. Popper, K. (2000). Notes on Berkeley as the predecessor of Mach and Einstein. Vestnik novgorodskogo gosudarstvennogo universiteta (Bulletin of Novgorod State University), 16. [In Russian].

\title{
Taras Mamenko
}

postgraduate student, $H$. Skovoroda Institute of Philosophy of the NAS of

Ukraine,e-mail: zlokara@i.ua

ORCID: https://orcid.org/0000-0003-1189-5711

\section{Comparative analysis of sign concepts of G. Berkeley and J. Lock}

\begin{abstract}
The article deals with Berkeley's semiotic views as alternatives to J. Lock's views. According to Locke, science deals not with things themselves, but with their signs. They are ideas that represent things for us and words that represent our ideas to others. Rejecting the materialist ontology, Berkeley rethinks the meaning of the linguistic sign. Since ideas cease to refer to things, and things are a combination of simple ideas, their meaning language signs (words) obtained through the connection between ideas. This gives grounds to speak about the functional significance of the sign in contrast to the substantive, where behind the word must be a particular material thing, or a clear idea. Berkeley also expands the functions of language, language is needed not only for the transmission of information, it can express emotion, will, belief, etc. It is noted that Berkeley, by striking the traditional modern ontology, lays the foundation for a non-substantive approach in understanding the sign. In Locke, the word sign derives its meaning from the idea behind it and which in turn takes its meaning from things. Berkeley, analyzing the language of view, notes that the sign indicates a connection between things, which gives us reason to talk about the functional meaning of the sign. The word doesn't make sense to him unless he has a clear idea behind it. Berkeley
\end{abstract}

Інститут філософії імені Г. С. Сковороди НАН України 
strongly criticizes the notion of force, substance, space, traditional for physics. Also important is the expansion of Berkeley's language. He concludes that, although Berkeley feels the need to search for common values not in things but in relations between ideas, he does not understand that it is impossible to explain common ideas only by the mechanics of simple ideas. Berkeley's critique of material substance had a great influence on the further development of philosophy.

Key words: G. Berkeley, J. Locke, sign, speech, word, idea, thing, sensation, semiotics.

\section{Тарас Маменко}

аспирант Института философии имени Г. С. Сковороды НАН Украины, e-mail: zlokara@i.ua,ORCID: https://orcid.org/0000-0003-1189-5711

\section{Сравнительный анализ концепций знака у Дю. Беркли и Дю. Локка}

\section{Аннотация}

В статье рассматриваются семиотические взгляды Дж. Беркли как алтернатива относительно парадигмальных для эпохи взглядов Дж. Локка. Отвергая материалистическую онтологию, Беркли переосмысливает значение языкового знака. Поскольку идеи перестают посылать к вещам, а вещи является комбинацией простых идей, свое значение языковые знаки (слова) получают благодаря связи между идеями. Это дает основание говорить о функииональном значении знака в отличие от субстанционального, где за словом долюна стоять конкретная материальная вещь, или четкая идея. Показано расширение Беркли функционирования языка, язык нужен не только для передачи информаичии, он может выражать эмочии, волю, убеждения и т.n.

Ключевые слова: Дж. Беркли, Дж. Локк, знак, речь, слово, мысль, вещь, чувство, семиотика. 